\title{
DATA ON WHITE STORK NESTS (Ciconia ciconia Linnaeus, 1758) FROM SEVERAL VILLAGES IN ARGEȘ COUNTY AND OLT COUNTY
}

\author{
Maria Denisa Conete ${ }^{1}$
}

${ }^{1}$ Faculty of Science, Physical Education and Informatics, University of Pitesti, Romania

\section{Current Trends in}

Natural Sciences

\begin{abstract}
In this paper is presented the situation of the White Stork breeding from several villages in the Argeş County and Olt County, in 2021. The data were collected during the White Stork Census in Romania, coordinated at the national level by the Romanian Ornithological Society (SOR) and Milvus Group. We checked the presence of nests in the 7 localities in Argeș County and Olt County using the car and the GPS track. The data is used to calculate numbers and study population trends of the species in Romania. An analysis was performed on several indicators (uH, HPo, HPm, Hpa, H, $J Z G)$ that characterize the reproduction, as well as other facts about the distribution. The results were compared with those from the previous White Stork census in Arges County, in 2004 and 2014. Although the population of the White Storks from Arges County shows a slight increase in this localities, the anthropogenic pressure is strong, in addition the dry climate, from the south of Arges County, strongly affects, at local level, the population of the White Storks.
\end{abstract}

Keywords: breeding success, villeges, White Storks.

\section{INTRODUCTION}

The situation of the White Stork (Ciconia ciconia Linnaeus, 1758) breeding in Romania was the subject for many researches. White Storks are well studied in most European countries, except the North. In Romania, in the 1980 census, the first in our country, data from 370 localities were centralized. In 1994, 778 localities were researched, and in 2004, 1994 localities were identified 4,414 nests (Petrescu, 2015). For Muntenia the presence of the species was reported by Maties (1969), Gava et al. (1997, 2004, 2007 etc.), Conete and Mestecaneanu (2004), Conete (2004, 2011, 2015, 2017, 2018 etc.) on the Arges valley, Conete et al. (2006, 2008, 2012), Mestecaneanu et al. (2004, 2008, 2012, 2014, 2017) and Danescu (2006). A detailed presentation of the research history was made in "Fauna Romaniei. Aves" (Petrescu, 2015).

Following several international censuses, the world population was estimated at 230,000 breeding pairs in 2004-2005 or 224,000-247,000 pairs, by IUCN, 2015 (http://www.iucnredlist.org). In Romania, the number varying between 4,000 and 6,000 pairs (Ciochia, 1992; Munteanu et al., 2002) or 5,000 - 6,000 pairs according to Reported national breeding population size and trends in Europe (BirdLife International European Red List of Birds, 2015).

White Stork is a sensitive indicator of anthropogenic influence such as intensive agriculture, pesticide application, habitat fragmentation, loss of wetland. Further, the White Stork is a protected 
species.Thus, monitoring the local population is important, the white stork being a good indicator of biodiversity (Tobolka et al., 2012).

\section{MATERIALS AND METHODS}

The data were collected during the White Stork Census in Romania, coordinated at the national level by the Romanian Ornithological Society (SOR) and the Milvus Group. The census was conducted in Muntenia, in several localities in the south of Argeș County and in the Northeast of Olt County. The Argeş County is situated in the Muntenia from the Southern part of Romania. It is $6826.3 \mathrm{~km}^{2}$ wide. The Olt County is located in the Southern part of the country, on the lower course of the river that gave it its name.

The characteristic climate of the area is temperate-continental with cold winters and warm summers with hilly characteristics (Barco and Nedelcu, 1974). The vegetation in the area of the lakes is specific to the southern hilly area. The hills are covered by deciduous forests, orchards and agricultural plots (Conete, 2015). Argeş County and Olt County has a rich hydrographic system. 7 localities (villages) from the 2 counties were investigated, 5 from Arges county and two from Olt county (Fig.1). The Bradu commune is located in the central part of Arges county, in the Western part of the High Plain of Pitesti, about $10 \mathrm{~km}$ from Pitesti, the residence of Arges county, being crossed by watercourses - Neajlov and Dambovnic rivers. The vegetal formations in the Bradu area belong to the forest-steppe area that occupies the vast majority of the territory, where the forest was cleared on large areas to be replaced with agricultural lands. The Neajlov river springs from the High Plain of Pitesti, at $306.5 \mathrm{~m}$ altitude. The vegetation largely loses its initial character, it becomes ruderalized, on some portions of land appearing irreversible changes, determined by the changes that have taken place in the environment of human impact.

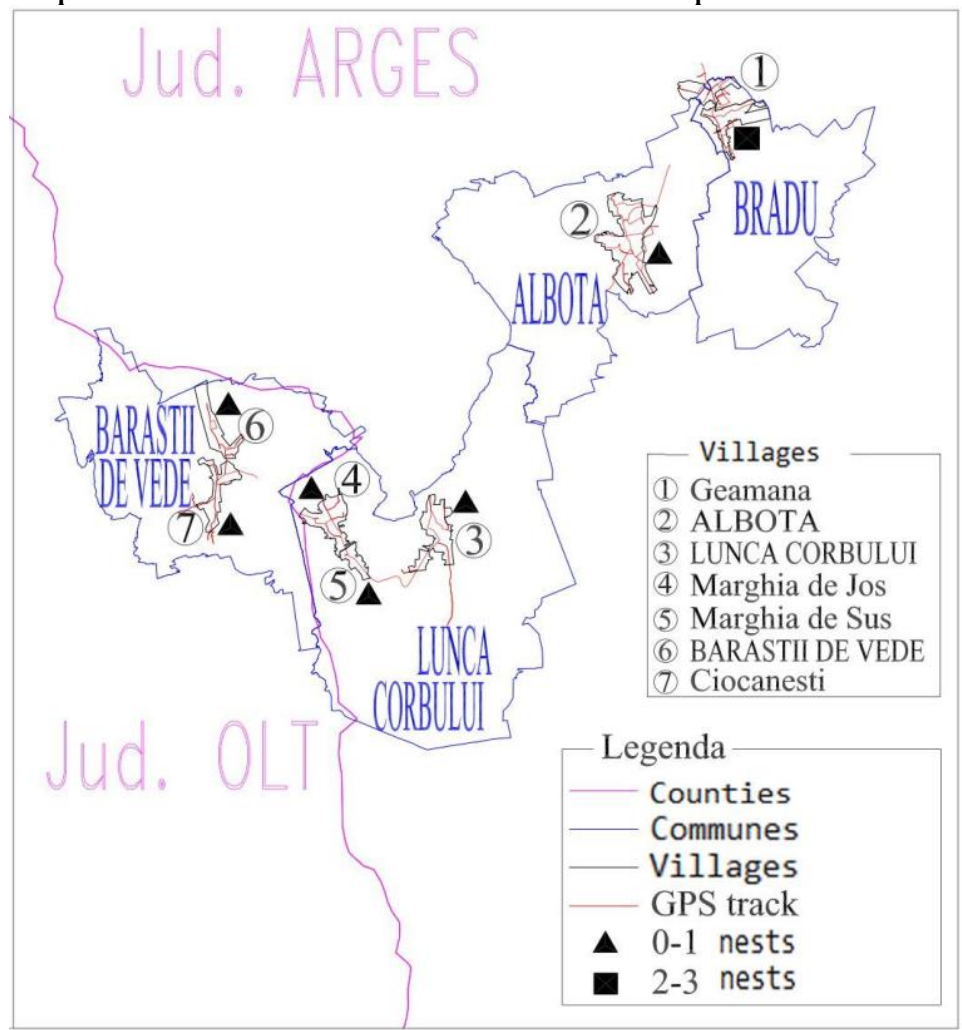

Figure 1. The distribution of the nests by localities (original map) 
Lunca Corbului is crossed by the Cotmeana river and Barastii de Vede is crossed by the Vedita river. In the natural forest-steppe vegetation, some associations with Poa bulbosa, Bothriochloa ischaemum, Artemisia austriaca, Cynodon dactylon, Bromus squarrosus, Festuca valesiaca, Agropyron cristatum and Stipa capillata predominate. In the forest-steppe, the woody vegetation is represented by Quercus pedunculiflora, Quercus pubescens, Quercus robur, along with which there are other species - Tilia tomentosa, Acer campestre, Fraxinus excelsior, Carpinus betulus and Corylus avellana.

In the meadow, the woody vegetation accompanies in the form of forest curtains the bottom of the valleys and is represented by hygrophilous species, swamp (willow, alder, acacia and poplar), being also subjected to an intense anthropic change by expanding agriculture, now being replaced by agricultural crops. The grassy vegetation in the meadow is differentiated according to the soil moisture regime. Invertebrates are also well developed in the area, especially insects. Vertebrates are represented here by a few species of fish, amphibians (Bufo viridis, Rana dalmatina, Pelophylax ridibundus, etc.), reptiles (Emys orbicularis, Natrix natrix, Lacerta viridis, etc), birds and mammals (Fratica and Ionete, 2012).

We checked the presence of nests in the 7 localities in Argeș County and Olt County using the car and the GPS track (Fig.1). The study was conducted during the breeding season on 24 July, 2021. Also, we used the application "Uite Barza!" Smartphone App (https://www.sor.ro/proiect/uitebarza/). A form was completed which included the localities, the geographical coordinates of the nests, the altitude, the status nest occupation (pair of chicks, pair without chicks, solitary bird, unoccupied nest), number of chicks, the location of the nest (electric pole, chimney, tree) and the date of observation. The nests were photographed and loaded into the application. The data is used to calculate numbers and study population trends of the species in Romania.

\section{RESULTS AND DISCUSSIONS}

7 nests were registered in the study area, 5 in Arges county and 2 in Olt county (Fig. 1, Fig. 2, Tab. 1). These were found as follows: 3 in Geamana (43\%), one in Albota (14\%) and one (14\%) in Lunca Corbului (Arges County). In Olt county, a nest was found in Barastii de Vede (14\%), near the river, with 3 chicks and unoccupied one (14\%), damaged in Ciocanesti, both in European ash (Fraxinus excelsior).

In the literature but also according to the White Stork Census from Romania (2004) the distribution of nests in trees is rare $(0.43 \%)$. In 1979, in Banat, Kiss found 10 nests in the European ash (Kiss, 1979; Petrescu, 2015). Currently, the number of nests built in European ash is decreasing, but in the study area ash is the favorite tree of the White Stork.

An analysis was performed on several indicators ( $\mathrm{uH}, \mathrm{HPo}, \mathrm{HPm}, \mathrm{Hpa}, \mathrm{H}, \mathrm{JZG})$ that characterize the reproduction, as well as other facts about the distribution. 4 nests carried chicks $-\mathrm{HPm}$ and 5 nests with couple - Hpa. The pairs having between 2 and 3 juveniles.10 chicks were counted in total (Tab. 1).

In the paper, the following parameters were used:

$\mathrm{uH}$ - the number of unoccupied nests;

HPo - the number of nests not bearing chicks;

$\mathrm{HPm}$ - the number of nests bearing chicks;

$\mathrm{HPa}$ - the number of couples (nests with couple);

$\mathrm{H}$ - the number of nests;

$\mathrm{JZG}$ - the number of chicks; 
The nests were generally placed on low voltage electrical poles. Thus, 3 nests were on electric poles without artificial supports, 2 nests with chicks on electric poles with supports and 2 nests in European ash (Fraxinus excelsior).

Table 1. The analysed parameters by localities

\begin{tabular}{|l|l|c|c|c|c|c|c|}
\hline No & Locality (Villages) & uH & HPo & HPm & HPa & H & JZG \\
\hline 1 & Geamana & 1 & 1 & 1 & 2 & 3 & 3 \\
\hline 2 & Albota & - & - & 1 & 1 & 1 & 2 \\
\hline 3 & Lunca Corbului & - & - & 1 & 1 & 1 & 2 \\
\hline 4 & Marghia de Sus & - & - & - & - & - & - \\
\hline 5 & Marghia de Jos & - & - & - & - & - & - \\
\hline 6 & Barastii de Vede & - & - & 1 & 1 & 1 & 3 \\
\hline 7 & Ciocanesti & 1 & - & - & - & 1 & - \\
\hline
\end{tabular}

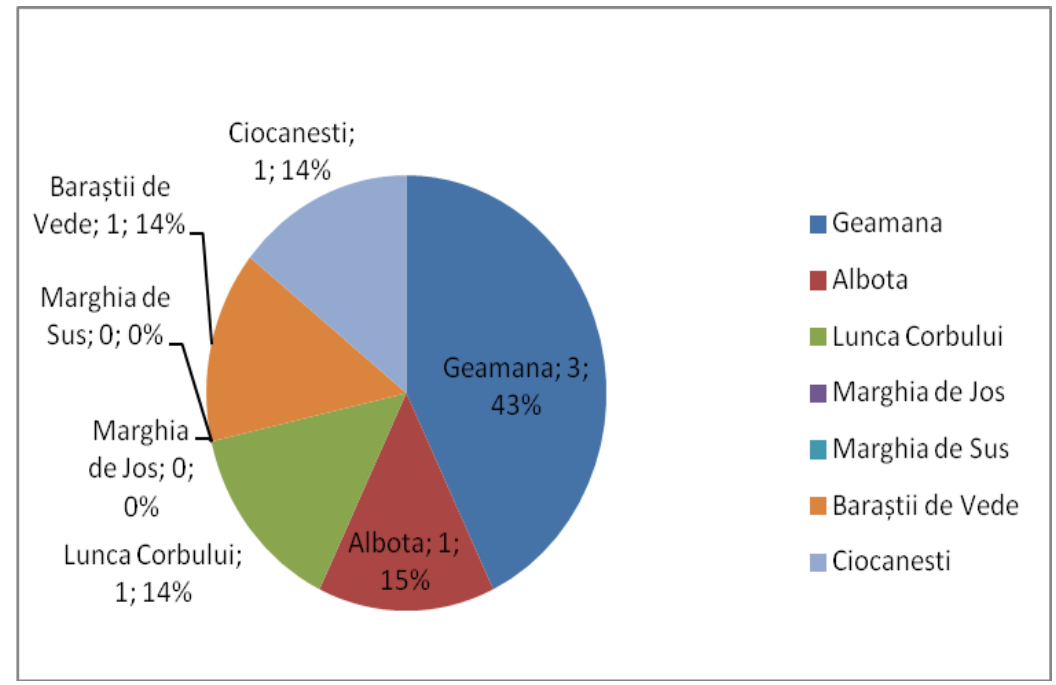

Figure 2. The number of nests in the researched villages

The altitude of the nests varied very little, the lowest at Lunca Corbului $(236 \mathrm{~m})$ and the highest at Geamana $(310 \mathrm{~m})$. The results were compared with those from the previous White Stork census in Argeş County, in 2004 and 2014.

In Lunca Corbului there were 3 nests recorded in the past (2004), we found only one. In Bradu (Geamana) a nest was registered, we noted 3 nests, and in Albota no nest was registered (2014), but we identified one. 2 nests were in the European ashes in Marghia, but they were cut down (according to the locals). We only found the stump that resulted after cutting the tree.

Regarding Olt County we do not have data for comparison. Although the population of the White Storks from Argeş County shows a slight increase in this localities, the anthropogenic pressure is strong, in addition the dry climate, from the south of Arges County strongly affects, at local level, the population of the White Storks.

\section{CONCLUSIONS}

During the White Stork Census conducted on 24 July, 2021, White Stork nests were found in 5 localities, in the south of Argeș County and in the Northeast of Olt County. 
The locality with the largest number of nests (43\% of all) was Geamana (Bradu). The pairs having between 2 and 3 juveniles.

Although in the literature the distribution of nests in trees is rare, in the researched area the number of nests built in European ash is remarkable, 2 out of 10 nests being located in trees.

The success of breeding is conditioned by the presence of unpolluted rivers (Neajlov, Cotmeana, Marghia, Vedita) and other wetlands. The dry climate in recent years in the study area as well as the absence of supports on electricity poles combined with the European ash cutting (Marghia de Sus, Marghia de Jos) has affected the population of the White Stork.

Also, White Stork is a sensitive indicator of anthropogenic influence, such as intensive agriculture, pesticide application, poisoning, habitat fragmentation, loss of wetlands, excessive aridity, etc. Monitoring the local population is important, the White Stork being a good indicator of biodiversity and human health.

It is necessary to place the supports on the electric poles in the localities where they are missing (Albota, Marghia de Sus, Marghia de Jos, Barastii de Vede si Ciocanesti) and it is strongly recommended to keep the healthy trees as a support for the nests. Only through action at the local level will positive results appear at the National, European or Global level.

\section{REFERENCES}

Barco, A., Nedelcu, E. (1974). Judeţul Argeş [Arges County]. Editura Academiei, Bucureşti.

Ciochia, V. (1992). Păsările clocitoare din România. Atlas. [Hatching birds in Romania. Atlas] Edit. Ştiinţifică. Bucureşti. 386 pp.

Conete, M. D. (2011). Cercetări ecologice asupra avifaunei unor lacuri de baraj din zona mijlocie a văii Argeşului [Ecological research on the avifauna of some dam lakes in the middle area of the Argeş valley]. PhD thesis. Institutul de Biologie al Academiei Române, Bucureşti.

Conete, M. D. (2015). Research study on the breeding avifauna of the Bascov reservoir. Current Trends in Natural Sciences. University of Piteşti, Faculty of Sciences, 4 (8), 23-36.

Conete, M.D. (2018). Rare, vulnerable and protected bird species in the area of the reservoirs from the middle basin of the Argeş river and measures for their protection. Current Trends in Natural Sciences, 7(14), 40-53.

Conete, M. D., Mestecăneanu, A., Gava, R. (2006). Speciile de păsări din situl AIA „Lacurile de acumulare de pe Argeş" protejate pe plan naţional şi european [Bird species from the AIA site "Argeş accumulation lakes" protected nationally and in Europe]. Argesis, Studii şi Comunicări, Ştiinţele Naturii, Muzeul Judeţean Argeş, Piteşti. 14: 103-115.

Conet,e D., Gava, R., Mestecăneanu, A., (2008). Statutul de protecţie al păsărilor din zona lacurilor de acumulare de pe râul Argeş [The protection status of the birds in the area of the accumulation lakes on the Argeş river]. Scripta Ornithologica Romaniae. Cluj-Napoca. 3, 68-75.

Frătică, F., Ionete, B. (2012). Bradu. Istorie și tradiție [Bradu. History and tradition], Editura Pământul

Gava, R., Mestecăneanu, A., Conete, D. (2004). The reservoirs of the Argeş River valley - important bird areas. Limnological Reports, Internat. Assoc. Danube. Res., Novi Sad, Sebia and Muntenegro. 35: 619-631.

Mestecăneanu, A., Conete, D., Gava, R. (2012). The census of the white stork (Ciconia ciconia L., 1758) in Argeş County, in 2004. Drobeta. Seria Ştiinţele Naturii. Muzeul Regiunii Porţilor de Fier. Drobeta Turnu Severin. 20: 53-65.

Mestecăneanu, A., Gava, R. (2013). The avifauna from Vâlcele, Budeasa, Bascov, Piteşti, and Goleşti basins observed in the prevernal season in 2013. Argesis. Studii şi comunicări, seria Ştiinţele Naturii, Muzeul Judeţean Argeş, Piteşti. 21: 71-86.

Mestecăneanu, A., Miu V., I., Badiu, D., L., Sterian, C., Bodescu, F. (2014). The Census of the White Stork (Ciconia ciconia Linnaeus, 1758) in the ROSPA0073 Măcin-Niculiţel and adjacent area, in 2013. Muzeul Olteniei Craiova. Oltenia. Studii şi comunicări. Ştiinţele Naturii. 30(2): 151-159.

Munteanu, D., Papadopol, A., Weber, P., (2002). Atlasul păsărilor clocitoare din România [The atlas of brooding birds in Romania], Second edition, Publicaţiile S.O.R., No. 16, 152 p. 


\section{Current Trends in Natural Sciences}

Vol. 10, Issue 20, pp. 186-191, 2021

https://doi.org/10.47068/ctns.2021.v10i20.025

Current Trends in Natural Sciences (on-line)

ISSN: 2284-953X

Current Trends in Natural Sciences (CD-Rom)

ISSN-L: 2284-9521

ISSN: 2284-9521

ISSN-L: 2284-9521

Petrescu, A. (2015). Ciconia ciconia (Linnaeus, 1758). Barza alba [White stork]. In: Munteanu D. (coord.) Fauna României. Aves. Galliformes, Ciconiiformes. Academia Română. Edit. Academiei Române. Bucureşti. 15(2): 212-259.

Tobolka, M., Sparks, T., H., Tryjanowski, P. (2012): Does the White Stork Ciconia ciconia reflect farmland bird diversity? Ornis Fennica 89 (early online)

http://www.birdlife.org/datazone/info/euroredlist

http://www.iucnredlist.org

https://www.sor.ro/proiect/uite-barza/ 